\title{
The Impact of Organizational Culture, Conflict Management, and Procedural Justice towards Normative Commitment of Human Resource at Stakpn Tarutung
}

\author{
Betty Arli Sonti Pakpahan
}

Lecturer of STAKPN Tarutung, Indonesia

\begin{abstract}
This study aims to find out the impact of organizational culture, conflict management, and procedural justice towards normative commitment of human resources in STAKPN Tarutung. The population of this research is all the staffs and lecturers around the campus with the total number in 154, and the sample is 110 by using proportionate stratified random sampling technique. Data gathering is using questionnaire in the form of Likert-scale, and following by data analysis by using path-analysis.The research result proving that : (1) organizational culture is positively and significantly impacting towards the normative commitment. (2) conflict management is positively and significantly impacting towards the normative commitment. (3) procedural juctice is positively and significantly impacting towards the normative commitment.
\end{abstract}

Hence, it is concluded that the stronger the organizational culture, the more effective conflict management, the higher procedural justice, then the higher will be the normative commitment of the human resources at STAKPN Tarutung, North Sumatera Indonesia. Practically, the result of this research can be implicated in improving the normative commitment of the human resource, it is suggestable to strengthen the organizational culture, to enhance the effevtiveness of conflict management, and empowering procedural justice.

Keywords - Organizational culture, Conflict management, Procedural justice, and Normative commitment.

\section{INTRODUCTION}

One point of the college quality standards of human resource in Indonesia is Commitment, as stated in National rules No. 20, year;2003, verse 40 (point b) it is about National education system, in which is stated that educators and staffs of a university have to have commitment proportionally for the purpose of improving educational www.ijels.com quality. In the same tone, Schatz $(1995 ; 67)$ states that commitment is a fundamental compulsory for every one to work, without commitment it is difficult for him to run his job well. However, there is phenomenon in some educational institutions that commitment is perceived as a challenge in all sides of life. Furthermore, according to some of the researchers that organizational commitment is the main challenge in the era of $21^{\text {st }}$, since in the circumstance of the institutions where they are working at is mostly covered by some anxiousness such as : job termination, work saveless, technology biases of which the workers are anxious upon the overwhelmed technology, ( Luthans 2006:248). There are some factors that impact the commitment of human resource such as : (1) individual mechanism factor, for instance; job satisfaction, learning, decision making, stresses, trust, justice, and ethics thar are automatically impact organizational commitment. (2) Organizationl mechanism factor, for instance ; organizational culture, organizational structure. (3) group mechanism factor, for instance ; leadership which covers style, behaviours, power and influence, and team that covers process and characteristics of the team itself. (4) individual factor, for instance : personaity and cultural values, ability, (see Colquitt, 2009:8). Furthermore, Work experiences(job scope, relationship, support, justice), role states (ambiguity, conflict, overload), and Psychological Contracts(economic exchange, social exchange), are also impact the organizational commitment, (Allen \& Meyer in Abdullah, Aldhuwaihi 2013:43). Organizational culture is an antecendent towards organizational commitment. Organizational culture basically is a value system which expand around the organization, such as permanent habits that are obeyed and applied by all the members of an organization.According to Mondy dan Noe, in Riani (2011:7), organizational culture can reform commitment for a manager and workers to apply things like ; programming, budgeting, controlling, monitoring, evaluating and so forth.

Page | 174 
According to Robbins (2008:264), culture can improve organizational commitment and workers concistence. Throughout a hormonismof culture between workers and an organization, it can reform organizational commitment of human resource.

Conflict management is also impact human resource (Meyer \& Allen 1997;106). Conflict management is perceived as the steps to follow as to overcome any conflicts for obtaining best solution and deliberation. Wirawan (2013:110) stated that conficts in an organization can be as motivation factors to improve creativity and innovation, if they are managed professionally, in contrary, if they are not managed properly they can decrease job satisfaction that automatically weaken commitment. Procedural justice also has a significant correlation with organizational commitment. Ivancevich et al (2006:161), describes that procedural justice has a positive correlation upon the habitual action such as commitment towards the organization, willingness to stay permanently in the organization, citizenship, trust, satisfaction and decision, efforts and performance in the organization. McShane\&Glinow (2005:163), procedural justice has significant correlation towards the emotion and attitude; the lower procedural justice, the lower trust and organizational commitment will be.The theoretic correlation above is supported by empiric study by: Yusuf (2017); Koesmono (2014); Taurisa, \& Ratnawati (2012), Firuzjaeyan, et al. (2015), in which they found that organizational culture has positive correlation with organizational commitment. On the other hand, Kassim (2014); Wanyonyi (2015); Ahmed Khaled \& Galal (2015), say that management styles are integratedly soving the problems to improve commitment. Moreover, Arti et al. (2009); Ali \& Saifullah (2014); Niazi \& Ali (2013), found that distributive and procedural justice have significant correlation with organizational commitment. Tarutung State Christian College (Tarutung SCC) is the only one of state college in Christian basis sitede in North Saumatera, West Indonesia, whereas the 6 others are located in the East of Indonesia (Ambon, Menado, Toraja, Palangkaraya, Kupang dan Papua).Tarutung SCC is legalized by Indonesia government to establish academic programs, profession and vocational program. Academic program which are running so far consists of : Undergraduate (S-1) and Postgraduate (S-2 \& S-3). Undergraduate majoring in 4 academic programs ; Christian Religiousity Education, Theology, Pastoral Counceling, Church Musical Education. Whereas,
Postgraduate majoring only 1 academic program it is Christian Religiousity Education. Vocational education is preparing the teachers of Sunday Learning Kids and the teachers of music of church. And, Profession Education serving education for the purpose of teachers certification.

Tarutung SCC is expandly in progress in all sides of; system, regulation, policy, technology, even the preparation to upgrade the status from Tarutung SCC becomes CSI (Christian State Institute). It certainly needs strong commitment of the human resource as the stakeholders of the campus, to maintain the unity in the organization, and to tackle the tasks to obtain the goals of the organization. In this article the writer would like to describe about the normative commitment of human resource( as independent variable) at Tarutung SCC with 4 dependent variables ; organization culture, Conflict management, Procedural justice and job description. Formulation of problem is as follows :

1. Is organizational culture significantly impacting upon normative commitment of human resource ?

2. Is conflict management significantly impacting upon normative commitment of human resource ?

3. Is procedural justice significantly impacting upon normative commitment of human resource?

\section{REVIEW OF LITERATURE}

The study is conducting by quantitative method using survey approach. Data gathering is by distributing questionnaire to the human resource at STAKPN Tarutung. Data analysis is using inferensial and descriptive technique wich is named GSCA (Generalised Structured Component Analysis). Descriptive analysis is applied to figure out the characteristic of data such as ; average, median, mode, frequence distribution. Whereas inferential analysis is used to test the hypothesis by using path analysis. The population of this study is all the staffs and lecturers in STAKPN Tarutung, it is 154 persons and derived to be 110 as the sample, using proportionate stratified random sampling. Data is gathered by using questionnaire in the form of Likert-scale in 5 criteria; $5=$ strong agree, $4=$ agree, $3=$ weak agree, 2 = disagree, $1=$ strong disagree. The reliability of instrument for variables is measured by Alpha Cronbach.

Below is the model of the research take from Jason A. Colquit, Jeffery A. LePine, Michael J.Wesson (2009) and Meyer J.,\& Allen, N.(1997) 


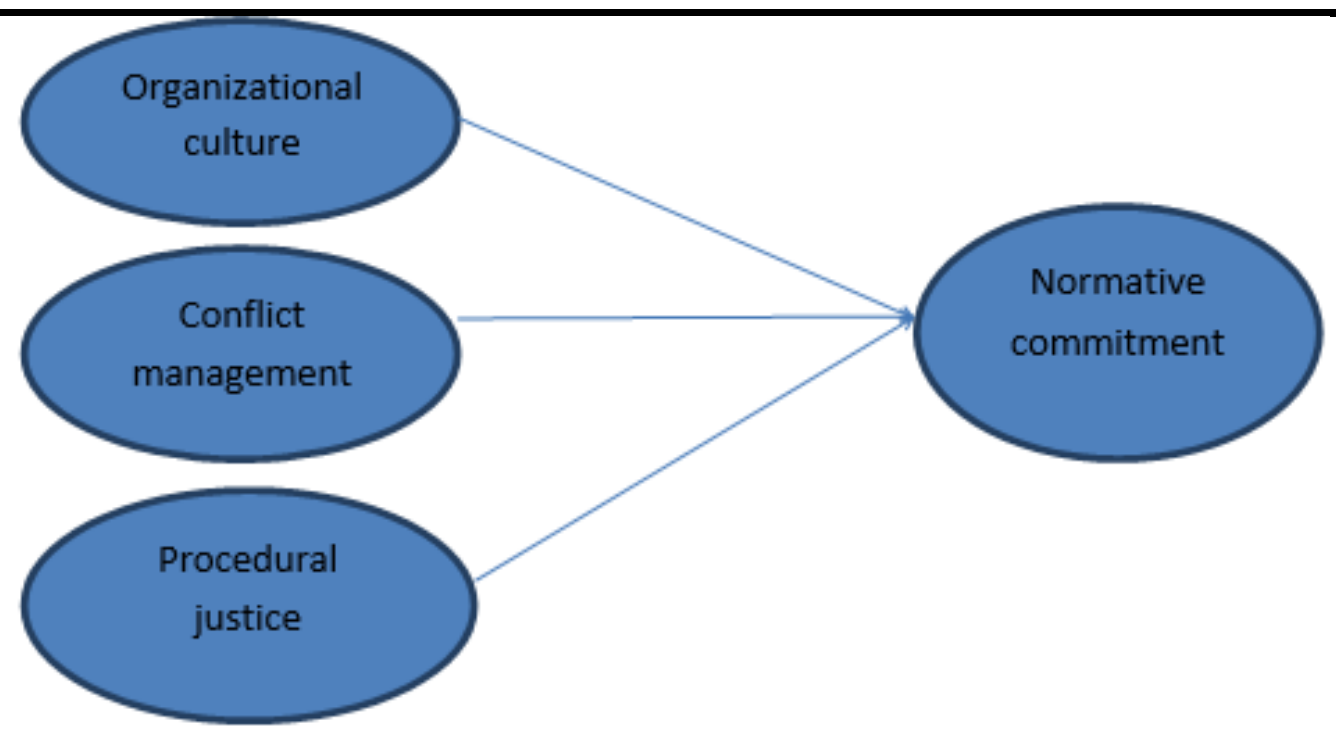

Picture-1. Theoretical framework

Hipotheses:

Hipotesis 1: Organizational culture is impacting normative commitment.

Hipotesis2: Conflict management is impacting normative commitment

Hipotesis 3: Procedural justice is impacting normative commitment.

\section{RESULT AND DISCUSSION}

Before the writer describes the research result,it is more suitable to present some of the expert idea regarding the variables of this research, as the theoretical basis in describing all the result dealing with the correlation among all the variables,independent variable and the dependent variable, as well. Normative commitment is as the dependent variable of this research. It is one of the organizational commitment components. According Allen dan Meyer (in Luthans 2006:249), there are 3 the components of organizational commitment, they are; (1) affectivecommitment, (2) continuance commitment, and (3). normative commitment. Those three components are different psychologically. The first commitment is affective commitment, is dealing with "want to" in the organization, whereas the second commitment is continuance commitment which is dealing with "need to", this is also should be maintain in an organization, and the third commitment is normative commitment which is dealing with compulsory or an ought to, this commitment should be maintained also in an organization to enhance the member or workers to have sense of belonging and have to work. According to Colquitt (2009:74) Normative commitment defined as a desire to remain a member of an organization due to a feeling of obligation. in this case, you stay because you ought to. Dengan pengertian; komitmen normatif, sebagai keinginan untuk tetap menjadi anggota organisasi karena rasa kewajiban, "stay because you ought to.Moreover, Normative commitment is a will to maintain as the member of an organization because of sense obligation, (Robbins 2009:101). In the same tone,Cut Zurnali (2010) states that, normative commitmentis sence of obligation to maintain existence in the organization because of having responsibility to the organization . those who possess high normative commitment will stay along and working well for the organization without thinking on the benefits side only, but because they are thinking using good morale, (Wiener in Bouarif, Nadia 2015. To Measure normative commitment, the writer prefers a questionnaire model by Allen \& Meyer ( 1997: 119) that covers: (1) frequence of members will to transwork from one organization to others. (2) believe to job faith in an organization. (3) transworking from one organization to others is not ethic. (4) faith is a good morale. (5) no transworking to other organizations eventhough they offer better benefits. (6) believe of fait values. (7) staying faithfully tends to career improvement. Regarding the theoretic description above, the writer will describe the result of the data analysis to prove the real correlation that found at STAKPN Tarutung human resource,as follows : 
Quantitative analysis from the 4 dependent variables are as follows :

Tabel 1

Frequencies

\begin{tabular}{|l|r|r|r|r|}
\hline & \multicolumn{1}{|c|}{ X1 } & \multicolumn{1}{c|}{ X2 } & \multicolumn{1}{c|}{ X3 } & \multicolumn{1}{c|}{ X4 } \\
\hline Valid & 110 & 110 & 110 & 110 \\
Missing & 0 & 0 & 0 & 0 \\
Mean & 106.45 & 105.69 & 106.93 & 117.26 \\
Median & 109.00 & 105.00 & 108.00 & 120.00 \\
Mode & $75^{\mathrm{a}}$ & 76 & 117 & 124 \\
Std. Deviation & 19.527 & 22.284 & 14.975 & 23.861 \\
Variance & 381.314 & 496.564 & 224.252 & 569.352 \\
Minimum & 70 & 65 & 70 & 70 \\
Maximum & 144 & 150 & 139 & 153 \\
\hline
\end{tabular}

$\mathrm{X}_{2}$ : Conflict management

$\mathrm{X}_{3}$ : Procedural justice

$\mathrm{X}_{4}$ : Normative commitment.

After administering the data quantitatively, it shows in the matrix correlation that the correlation betweenCultural Organization (X1) withNormative commitment (X4) equals to 0.347 , the correlation between Conflict management (X2) withNormative commitment (X4) equals to 0.298 , the correlation between procedural justice (X3) with Normative commitment (X4) equals to 0.342 .

Tabel 2

Correlations

\begin{tabular}{|l|r|r|r|r|}
\hline & \multicolumn{1}{|c|}{ X1 } & \multicolumn{1}{c|}{ X2 } & \multicolumn{1}{c|}{ X3 } & \multicolumn{1}{c|}{ X4 } \\
\hline Pearson Correlation & 1 & .075 & .164 & $.347^{* *}$ \\
Sig. (2-tailed) & & .436 & .087 & .000 \\
$\mathrm{~N}$ & 110 & 110 & 110 & 110 \\
\hline Pearson Correlation & .075 & 1 & .137 & $.298^{* *}$ \\
Sig. (2-tailed) & .436 & & .154 & .002 \\
$\mathrm{~N}$ & 110 & 110 & 110 & 110 \\
\hline Pearson Correlation & .164 & .137 & 1 & $.342^{* *}$ \\
Sig. (2-tailed) & .087 & .154 & & .000 \\
$\mathrm{~N}$ & 110 & 110 & 110 & 110 \\
\hline Pearson Correlation & $.347^{* *}$ & $.298^{* *}$ & $.342^{* *}$ & 1 \\
Sig. (2-tailed) & .000 & .002 & .000 & \\
$\mathrm{~N}$ & 110 & 110 & 110 & 110 \\
\hline
\end{tabular}

level (2-tailed).

Path analysis shows that organizational culture is significantly impacting upon normative commitment of human resource $(\beta=0,194, \mathrm{t}=2,105, \mathrm{p}<0,05)$. Conflict management is significantly impacting upon the Normative www.ijels.com commitment of human resource $(\beta=0,188, \mathrm{t}=2,182, \mathrm{p}$ $<0,05)$. Procedural justice is significantly impacting upon the Normative commitment of human resource $(\beta=0,189$, $\mathrm{t}=2$. 105, $\mathrm{p}<0,05)$. As being seen in the matrix that organizational culture is significantly impacting upon the normative commitment with $(\beta=0.189, \mathrm{t}=0.189, \mathrm{p}$ $<0,05)$, means that tha $\beta$-obtained (0.189) and t-obtained (2.105) exceeds further than 0.01 as the significant level, and this is the significance value found in this research dealing with organizational culture. It is reasonable to say that organizational culture is the basis of values system that expands in an organization in the form of habits that seems permanent and progressing on, obeyed by all members in the institutions. Schein (2004:168), proclaims thatorganizational culture is a system of togetherness inference which is taken by all members to distinguish one another. Moreover, Robbins (2008:256), says that organizational culture is a system of togethetness having by the members that can compare to another organization, culture as binder of values or norms and organization as a perspective for members to act in the same vision.In this case, organizational culture can be functioning as a frame of cognition chain that consists of ; attitude, values, norms, and characters that are received by all members, seeGreenberg dan Baron (2003:515). The culture of organization can improve the commitment and the consistence of the members. To have it welldone, it is suggested to apply familiarization process around the organization. The more members possessing core values, the higher members' commitment wil be. According to Robbins (2008); O'Reilly et al (1991:516); there are 7 characteristics of organizational culture: 1) Inovation and risk taking, 2)detailed thinking, 3) result orientation, 4) human Orientation, 5) team orientation, 6)eagerness, 7) Stability. Next, the second independent variable is conflict management. Path analysis shows that $(\beta=0,188, \mathrm{t}=$ $2,182, \mathrm{p}<0,05)$ means that the $\beta$-obtained $(0.188)$ and $\mathrm{t}-$ obtained (2.182) exceed further than 0.01 as the significant level standard, and this is the significance value found in this research dealing with conflict management. It is reasonable to say that conflict management is the basis of values system that expands in an organization in the form of habits that seems permanent and progressing on, obeyed by all members in the institutions. Conflict management is a technique or strategy, rules used by the people who are in conflict to decrease or to solve a conflict exsisting in an organization.According to Hellriegel (2009:358), conflict management refers to the diagnostic processes, interpersonal styles, and negotiation strategies that are designed to avoid unnecessary conflict and reduce or resolve excessive conflict. Robbins (2008:184), conflict

Page | 177 
management is technique resolution or simulation use to obtain conclict level which is earned. Wijono(1993), states that there are 3 strategies in overcoming a conflict; 1) loselose strategy, 2) win-lose strategy, dan 3) win-win strategy, but all is in one purpose,that is to win together and gaining the goal together. Covey (1994:203) suggests that win-win strategy is the best one to apply, since it is the basis of all interaction models successfulness, and the successfulness of self-strength and organization, as well. Win-win solution offers benefits and satisfaction for all the people involving, in which they find map of thinking togetherly, hand in hand and dependently obtain the goals of the organization,so that they effort to manage the conflict without any hurting, see Whetten dan Cameron (in Luthans 2009:464), he moreover states that to obtain successfulness and benefits togetherly, it is need to apply integrative approach (win-win solution) since it can pursue winning for togetherness. Both the sides are winning the benefits, none of sides is defeated as has been agreed in the agreement. Some indicators that influence conflict management style or even win-win strategy, they are; (a) listen carefully to what the opposite or rival talking about, (b) the ability to negotiate, (c) identifying the ideas of the rival, (d) having confrontation out of threat,(e) analyzing inputs, (f) having consequence, see(Wirawan 2013:142). The third independent variable is procedural justice. Path analysis tells out that Procedural justice is significantly impacting upon the Normative commitment of human resource $(\beta=0,189, \mathrm{t}=2.105, \mathrm{p}$ $<0,05)$. It is proved that $\beta$-obtained $(0.189)$ and t-obtained (2.105) exceed further than 0.01 as the significant level standard, and this is the significance value found in this research dealing withprocedural justice. It is reasonable to say thatprocedural justice is the basis of values system that expands in an organization in the form of habits that seems permanent and progressing on, obeyed by all members in the institutions.Procedural justice is a borometer of fairness in an organization, of which the members have their own perspective against the final decision making in an organization. According to Colquitt et al.(2008;226-231), procedural justice consists of 4 dimensions; distributive justice, procedural justice, interpersonal Justice, and informational justice. Those four dimensions tend to; (1) distributive justice concerning on decision placement, (2) procedural justice, concerning on the process of decision making, (3) interpersonal justice ,concerning on top-down policy, (4) informative justice, concerning on information availability from the organization. In this study the writer is focusing on the procedural justice in decision making. Procedural justice is the fairness given by the organization to the members of which they saved, mutual, and welltreatment, seeRobbins (2008:250),Gibson et.al. (2009:152), they tend to emphasize that procedural justice is the perception of fairness of the process used to distribute rewards. Moreover,Robert Kreitner ( 2007:244) claims thatprocedural justice is defined as the perceived fairness of the process and procedures used to make allocation decisions. Characteristics of procedural justice according to Colquit (2009); Cropanzano et.al (2013); Yuwono (2005) are: voice, correctability, consistency, bias suppression, representativeness, accuracy, etis.

Table 3

Coefficients $^{a}$

\begin{tabular}{|c|c|c|c|c|c|}
\hline \multirow[b]{2}{*}{ Model } & \multicolumn{2}{|c|}{$\begin{array}{l}\text { Unstandardized } \\
\text { Coefficients }\end{array}$} & \multirow{2}{*}{\begin{tabular}{|c|}
$\begin{array}{c}\text { Standardized } \\
\text { Coefficients }\end{array}$ \\
Beta
\end{tabular}} & \multirow[b]{2}{*}{$\mathrm{T}$} & \multirow[b]{2}{*}{ Sig. } \\
\hline & B & $\begin{array}{l}\text { Std. } \\
\text { Error }\end{array}$ & & & \\
\hline $\begin{array}{l}\text { (Constan } \\
\text { t) }\end{array}$ & 5.821 & 17.903 & & .325 & .746 \\
\hline $\mathrm{X} 1$ & .238 & .113 & .194 & 2.105 & .038 \\
\hline $\mathrm{X} 2$ & .201 & .092 & .188 & 2.182 & .031 \\
\hline X3 & .301 & .143 & .189 & 2.107 & .037 \\
\hline
\end{tabular}

Dependent Variable: X4

Based on the path analysis and coefficient residue, in which; $\mathrm{R}^{2}{ }_{4(123)}=0,371$, then the similarity in path analysis is; $X_{4}=0,388 X_{1}+0,226 X_{2}+0,311 X_{3}+0,629$. The result of structural model analysis is as the following chart: 


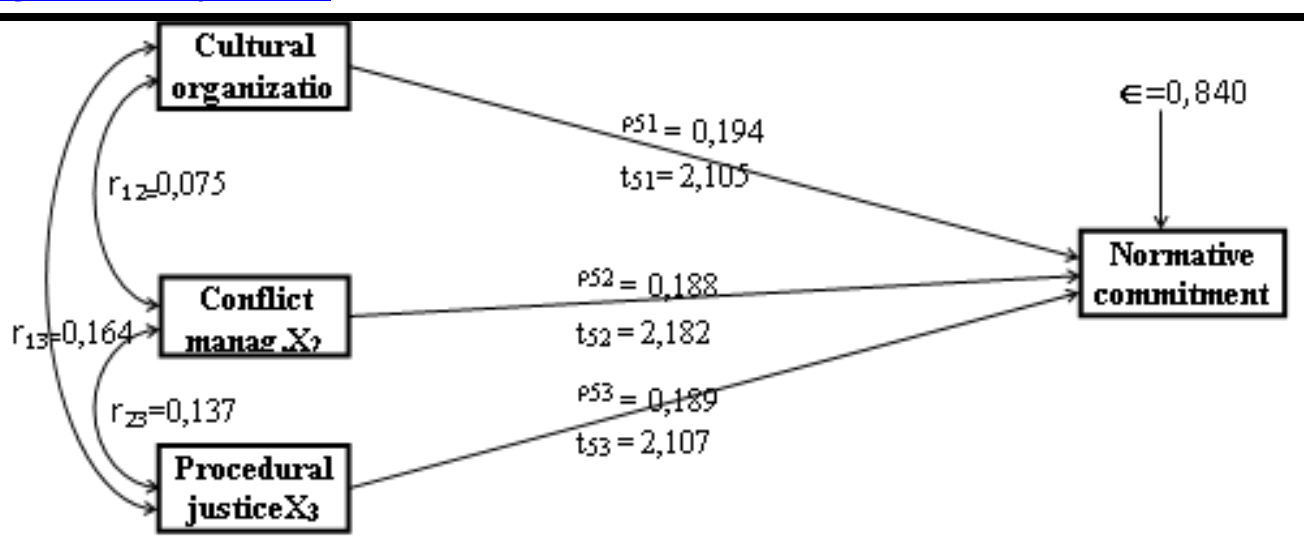

Chart-2: coefficient-correlation of path analysis and t-test.

\section{CONCLUSION}

This study proves that (1) organizational culture is significantly and positively impacting the normative commitment. The stronger the organizational culture,the higher normative commitment will be in STAKPN Tarutung . (2) conflict management is significantly and positivelyimpacting towards the normative commitment. The more effective conflict management, the higher normative commitment will be in STAKPN Tarutung. (3) procedural juctice is positively and significantly impacting towards the normative commitment. The higher the perception of human recource against the organisation, the higher normative commitment will be at STAKPN Tarutung. Theoretically, the result of this study has confirmed various factors that are predicted to raise up the normative commitment of human resource at STAKPN Tarutung, such as; organisational culture, conflict management, and procedural justice. As the result, coefficient residue is $0.629=62.9 \%$, as the outsider factor that impact normative commitment of human resource in doing their job regarding the location of this research. The implication of policy that suggested in this study is as follows : (1) organizational culture variable is significantly impacting normative commitment. Hence, it is important to strengthen and maintain antecedent organizational culture and the relevant one to improve the normative commitment of human resource. Besides, familiarizing all-out about vision and mission, values, and rules, in the organization,so that the human resource understanding their tasks and responsibility to gain the goals of the institution. Legitimation of the rules in written to avoid negative perception and concistently implicate it to obtain synergic between staffs and lecturers at STAKPN Tarutung. Creating comfortable communication among the members, and supporting the human resource to have innovation, eagerness, being a rolemodel, having competence edging the works, working based on terms and condition. (2) Conflict management has a huge impact towards normative commitment, it is reasonable to manage conflict effectively, improving the normative commitment of the human resource. Hence, it is important to create effective communication from top-down or bottom-up, legitimating the rules and certain procedures, creating nice circumstance among all the stakeholders, respecting one each other. (3) procedural justice has a great impact upon the normative commitment, it is suggested to : give a fair chance for all the human resource to attend quality time and give a chance to express their inspirations, make decision in a good manner, decision is opened for all the stakeholders, apply the fair right and responsibility for all the human resource, revise expired rules and decision thar not suitable to the recent condition, draw a hierarchy and the structure of decision making, apply the reward and punishment system as a concistency in the organization.

\section{REFERENCES}

[1] Ahmed, K., and Ahmed G. 2015. The Relationship between Conflict Management Style, Job Satisfaction and Organizational Commitment among Workers in Publik and Private Sectors, Universal Journal of Psychology 3 (2).

[2] Aldhuwaihi A.2013. The Influence Of Organisational Culture On Job Satisfaction, Organisational Commitment and Turnover Intention: A Study On The Banking Cector In The Kingdom Of Saudi Arabia.

[3] Allen, N.J., \& Meyer, J.P. 1990. The measurement and antecedents of affective,continuance, and normative commitment to organization.Journal of occupationalpsychology.

[4] Ali, M., and Zahid, S. 2014. Distributive and procedural Justice as Predictors of Job satisfaction and Organizational Commitment: A Case Study of 
Banking Sector of Balochistan. Journal of Information

Engineering and Applications, ISSN 2224-5782 (print)

ISSN 2225-0506 (online) Vol.4, No.11. pp. 25-31.

[5] AmirullahH.B. 2004. Pengantar Manajemen. Edisi kedua, Yokyakarta;Graha Ilmu.

[6] Amna N., and Muhammad A. F. 2013. The Relationship between Organizational Justice and Organizational Commitment and the Mediating Effect of Job Satisfaction on Organizational Behavior, International Journal of Management Sciences and Business Research, ISSN (2226-8235) Vol-3, Issue 2.

[7] Arwildayanto. 2012. Manajemen Sumber Daya Manusia Peguruan Tinggi; Pendekatan Budaya Kerja Dosen Profesional”, Ideas Publishing. https://www.google.co.id,

[8] Bakhshi Arti, dkk. 2009. Organizational Justice Perceptions as Predictor of Job Satisfaction and Organization Commitment, international Journal of Bisnis and Management, vol.4, no.9,

[9] Bouarif, N. 2015. Predicting Organizational Commitment: The Role of Religiosity and Ethical Ideology. Journal; European Scientific, june edition vol.11, No.17. ISSN: $1857-7881$.

[10] Brown, A. 1990.Organization Culture, Second Edition, Prentice Hall Brown. 